\title{
Unequal glandular differentiation of the equine endometrium - a separate endometrial alteration?
}

\author{
Lisa Bischofberger, Kristin Szewczyk and Heinz-Adolf Schoon \\ Institute of Pathology, Faculty of Veterinary Medicine, University of Leipzig
}

\begin{abstract}
Summary: Endometrosis as well as unequal glandular differentiation (UGD) present alterations of glands, whose epithelial cells are deviating from the physiological stage of the cycle regarding function and/or activity. Therefore, both diseases are known to reduce the fertility of mares. Due to the periglandular fibrosis occurring in endometrosis it is considered to be irreversible while UGD is supposed to be reversible. Histomorphological examinations reveal an onion-skin-like periglandular arrangement of stromal cells (PSC) surrounding the altered glands in endometrosis. This study should compare the histomorpological appearance, especially the occurrence of PSC not only in endometrosis but in UGD as well. For this purpose, 23 mares suffering from UGD and endometrosis $(n=10$, group 1), UGD and irregular glandular differentiation (IGD, $n=3$, group 2) or UGD, endometrosis and IGD ( $n=10$, group 3) were chosen. The control biopsies were either unchanged or suffering from mild endometrosis (each $n=5$ ). Serial slides of 33 endometrial tissue specimens (experimental group: $n=23$, unchanged and fibrotic controls: each $n=5$ ) collected within the physiological breeding season were prepared and per mare three of them were stained by routine stain H.E. (hematoxylin and eosin). Additionally, the immunohistological expression pattern of $\alpha$-smooth-muscle-actin, desmin and vimentin was examined to find out if there are analogue results in UGD and in endometrosis. For this purpose, the other slide levels were treated by immunohistochemical methods for $\alpha$-smooth-muscle-actin, desmin and vimentin (each $\mathrm{n}=3$ per mare). Histomorphologically, a distinct increase of PSC (number of layers as well as percentage of the gland surrounded by the PSC) could be detected in deeper levels of the H.E.-slides. As seen in endometrosis, UGD also presented a PSC around the affected glands which partially also was of onion-skin-like appearance. The immunohistochemical examination revealed an expression of $\alpha$-actin in stromal cells within UGD that was weaker than in endometrosis but stronger than in unchanged areas. According to the findings of other authors, $\alpha$-actin is expressed already in early stages of endometrosis. Regarding the expression of desmin, it was more often expressed by stromal cells within UGD than in unchanged areas while the expression was of lower intensity in UGD. Both findings are seen in endometrosis in the own study and also are known from UGD. Different authors saw a variable expression of desmin subject to the degree or character of endometrosis. Vimentin could be detected in stromal cells within UGD with higher percentage but lower intensity of expression compared to the unchanged stromal cells. As also viewable in endometrosis, it was expressed in epithelial cells of UGD-areas with strong intensity. Due to the histomorphological examinations and the expression pattern of $\alpha$-actin, desmin and vimentin in UGD, the results resemble those of endometrosis in wide parts. Therefore, it can be concluded that UGD is an early form of endometrosis. This has to be prooven by follow-up-studies regarding the development of UGD/endometrosis during a defined period of time.
\end{abstract}

Keywords: reproduction, mare, maldifferentiation, unequal glandular differentiation, endometrosis, histomorphology, immunohistochemistry

Citation: Bischofberger L., Szewczyk K., Schoon H.-A. (2019) Unequal glandular differentiation of the equine endometrium - a separate endometrial alteration? Pferdeheilkunde 35, 304-315; DOI 10.21836/PEM20190401

Correspondence: Lisa Bischofberger, Institut für Veterinär-Pathologie, An den Tierkliniken 33, 04103 Leipzig, Germany; I.bischofberger@gmx.net

Received: April 19, 2019 | Accepted: May 20, 2019

\section{Introduction}

Endometrosis is defined as irreversible periglandular and/or stromal fibrosis including glandular alterations (Kenney 1992, Schoon and Schoon 1995, Schoon et al. 1997). The epithelial cells of the affected single glands or glandular "nests" (Kenney 1978, Schoon et al. 1992) are characterized by a function deviating from the stage of the ovarian cycle (Schoon et al. 2000, Schoon and Schoon 2003). Endometrosis is responsible for restricted functionality of the equine endometrium in view of gestation and their maintenance (Schoon 1992), because it can cause early embryonic death and abortion (fetal loss; Doig et al. 1981). The alterations can be found in over $95 \%$ of the mares barren for a minimum of two years (Schoon et al.1997). While the severity of endometrosis increases with the average number of years barren and the age of the affected mares, it is independent on the parity (Schoon et al. 1997).

Endometrial maldifferentiation also presents glands differing from the predominant endometrial appearance. During the breeding season, it causes shortened cycle intervals and a lack of typical estrus symptoms (Schoon et al. 1999). This alteration is subdivided in two groups:

The "unequal glandular differentiation" (UGD) is characterized by an aberrant activity or cyclic function of the affected glands which is deviating from the endometrial glands differentiated consistent with the stage of the cycle (Schoon et al. 1999, Häfner et al. 2001). It is mostly found within a glandular accumulation ("nest") without a distinct border to the 
unchanged endometrium (Schoon et al. 1999, Häfner et al. 2001). Both authors assumed UGD to be a result of a localized damage of endometrial hormone receptors and therefore causes a hormonal dysfunction/partially hormone-refractory endometrium. Moreover, changes in the differentiation of periglandular stromal cells, not detectable by light microscopy, are discussed (Häfner et al. 2001).

The "irregular glandular differentiation" (IGD) shows a polymorphy of epithelial cells within one gland cross-section (Schoon et al. 2000) and is supposed to be caused by hormonal dysregulations of different origin (Schoon et al. 1999, Ellenberger et al. 2002, Häfner et al. 2001). Some glands cannot be appointed to any kind of physiological differentiation (Schoon et al. 1999, Schoon et al. 2000).

In general, a correlation with age, reproductive status, parity or season is not detectable for endometrial maldifferentiations (Schoon et al. 1999), although an accumulation of IGD can be found in middle aged mares ( $11-15$ years of age).

The affected glands of endometrosis and UGD present a function deviating from the stage of the ovarian cycle. The only difference between the alterations is the periglandular and/ or stromal fibrosis, which is only detectable in endometrosis. Therefore, it can be hypothesized that unequal glandular differentiation is not a seperate endometrial change but rather an early stage and/or margin cut of endometrosis. Thus, the aim of the present study was a histomorphological and immunohistochemical investigation of serial slides of endometrial biopsies with UGD. In this context, the immunohistochemical expression-pattern of periglandular stromal and glandular cells in UGD in different levels was compared to the one of endometrosis.

\section{Material and methods}

Animals and selection of biopsies for investigation

For the present study archived routine endometrial biopsy specimens of mares sent to the Institute of Pathology, Faculty of Veterinary Medicine, University of Leipzig between 19982012 were scanned for the diagnosis UGD. They were fixed in $4 \%$ neutral buffered formalin and embedded in paraplast.

At last 23 endometrial biopsies out of 23 mares aged 8-23 years (age unknown in 6 mares, average age of the others: 16.12 years) were chosen for investigation. All specimens were taken within the physiological breeding-season (April to September) and (at least) characterized by an UGD. The mares gave birth to a minimum of one up to three foals $(n=10)$ or were maiden mares $(n=5)$, most of them were not or less than two years $(n=10)$, some more than 2 years $(n=4)$ barren or the time of barrenness was not given $(n=9)$.

Five biopsies from the archive without any pathological alterations (average age: 9.25 years, age unknown $n=1$ ) and 5 tissue samples with mild endometrosis (average age of the mares: 12.4 years) served as controls.
Histomorphological investigation

The 33 biopsies (UGD-animals and controls) were investigated regarding the activity and cyclic function of the endometrial glands and also the occurrence of additional endometrial changes (endometritis, endometrosis, angiosclerosis, IGD, lymphangiectasias, lymphlacunas). Depending on them and the time of barenness the mares were categorized according to Kenney and Doig (1986) and Schoon et al. (1992, 1997). In cases of maldifferentiation a classification according to Häfner (1999) was carried out: proliferative/inactive unequal differentiation; proliferative/secretory irregular differentiation; completely unequal/irregular differentiation.

Histomorphological and immunohistochemical investigation of UGD

Special attention was focused on "periglandular arranged stromal cells" (following called PSC) within UGD, that could indicate an early stage of endometrosis. In this context, (i) the content (\%) of glands with PSC within UGD-areas, (ii) the completeness of this periglandular arrangement (quarter, half, three-quarter, complete) and (iii) the thickness of this PSC (one layer; 2-3; 4-5; > 5 layers) within the different slide-levels was estimated.

To detect changes of stromal and/or glandular cells in deeper areas of nests with UGD, 19 serial slides ("slide-levels"; $\mathrm{SL}$ ) of the 23 UGD-biopsies and the controls were prepared (thickness: 2-3 $\mu \mathrm{m}$ ) and stained by hematoxylin and eosin (H.-E.; Welsch and Riedesheimer 2010; slide level: 1, 6, 11) or treated by immunohistochemical methods:

The expression of $\alpha$-smooth-muscle-actin ( $\alpha$-actin; dilution 1 in 100; Dako Diagnostika GmbH, Hamburg, Germany ("Dako"); slide-level: 2, 7, 12), desmin (1 in 400; Dako; slide-level: 3, 8, 13) and vimentin (1 in 400; Dako; slide-level: 4, 9, 14) was evaluated.

The sections were dewaxed, rehydrated and treated with hydrogene peroxide $0,5 \%$ in methanol for $30 \mathrm{~min}$ at room temperature (RT) to eliminate endogenous peroxidase activity. After washing in Tris-buffered saline (TBS) for $5 \mathrm{~min}$, no pre-treatment was necessary.

Afterwards, $100 \mu \mathrm{l}$ of the diluted primary antibodies were mustered to the sections. The mononclonal antibodies (mab: $\alpha$-actin, desmin, vimentin) were diluted in BSA $1 \%$. The ideal dilution and incubation temperature was determined in preliminary tests. The primary antibodies were replaced by a monoclonal antibody against surface antigen of chicken bursa lymphocytes (T1, Hirschberger 1987). All antibodies were applied to the sections overnight at $4{ }^{\circ} \mathrm{C}$.

The slides with the antibodies for desmin and vimentin were incubated for 30 minutes at RT with Histofine Simple Stain MAX PO Multi (Medac, Wedel, Germany).

After signal detection with a freshly prepared solution of 3,3'-diaminobenzidin-tetrahydrochloride (DAB; Fluka Feinchemikalien, Neu Ulm, Germany) for $10 \mathrm{~min}$ at RT, the sec- 
tions were counterstained with Papanicolaou's stain and finally dehydrated.

Positive controls consisted of skeletal muscle (desmin), smooth muscle of vessels ( $\alpha$-actin) from horses and skin of a dog (vimentin).

The stained sections were evaluated by light microscopy to determine the proportion of immunolabelled intracytoplasmatic cells/structures. Immunoreactivity was assessed by examination of the luminal/glandular epithelium and periglandular stromal cells of unchanged as well as of areas with UGD or endometrosis. Regarding one area and one cell population (e.g. glandular cells) a semiquantitative analysis was conducted: the proportion of immunolabelled cells was defined as the ratio of immunopositive cells to the total number of cells in $10 \mathrm{HPFs}$ and the values were expressed as "percentage of immunopositive cells" (PP) as follows: 0 , no PP; $\leq 10 \%$ PP; 11-20\%; 21-40\%; 41-50\%; 51-80\%; 81-100\% PP. The staining-intensity was assessed as follows: -, negative; $(+)$, slight; + , mild; $+(+)$, mild to moderate; ++ , moderate; $++(+)$, moderate to strong; +++ , strong. If the expression-pattern of periglandular stromal cells inside UGD or endometrosis varied, the predominant expression-pattern was noted. No statistical analyses were carried out.

\section{Results}

\section{Histomorphological findings}

\section{Control animals:}

The endometrium of the controls without pathological alterations $(n=5)$ showed slight $(n=2)$ or mild $(n=1)$ lymphangiectasia. Therefore, the mares could be assigned to Category I (proliferative: $\mathrm{n}=3$, proliferative to secretory, secretory each: $\mathrm{n}=1)$.

Another five biopsies (proliferative: $n=3$; proliferative to secretory, secretory each: $n=1$ ) were used as control due to the occurrence of a mild endometrosis. Additionally, 2 of these samples showed mild angiosclerosis and slight/mild lymphangiectasia. Considering the time of barrenness ( $\geq 2$ years: $n=1)$, the 5 mares could be assigned to Category lla $(n=3)$, $\| a / b(n=1)$ or $\| b(n=1)$.

\section{UGD-animals:}

Histomorphological findings, categorization and stromal cells: The unaffected endometrial areas of the UGD-animals $(n=23)$ were characterized by a mild $(n=3)$, mild to moderate $(n=6)$ or moderate $(n=14)$ activity with proliferative $(n=13)$, proliferative to secretory or secretory to proliferative (each: $n=5$ ) differentiation. Regarding the additive endometrial changes detected in all samples, the 23 UGD-animals were subdivided:

The endometria of group $1(G 1 ; n=10)$ were characterized by UGD and endometrosis (mild: $n=2$; mild to moderate: $\mathrm{n}=2$; moderate $\mathrm{n}=4$; moderate to strong: $\mathrm{n}=2$ ). Further findings were angiosclerosis $(n=9)$, lymphangiectasia $(n=6)$, endometritis (non-purulent: $n=3$, mixed: $n=1$ ) of variable degree. Also regarding the years barren ( $\geq 2$ years: $n=1$; not given: $n=4)$, these 10 animals were attributed to Category Ila $(n=3), \| b(n=5)$, III $(n=2)$.

Group $2(G 2 ; n=3)$ contained endometria with a co-occurrence of UGD and IGD (proliferative, proliferative to secretory, secretory: each $n=1)$. Furthermore angiosclerosis $(n=3)$, lymphangiectasia $(n=2)$ and a mild, non-purulent endometritis $(n=1)$ were found. Considering the years barren $(\geq 2$ years: $n=2)$, the mares were assigned to Category I, Ila and Ila/llb.

The group 3-mares (G3; $n=10$ ) revealed UGD, IGD (proliferative: $n=5$; proliferative to secretory: $n=2$; secretory to proliferative: $n=3$ ) and endometrosis of variable degree (mild: $n=3$; mild to moderate: $n=5$; moderate: $n=2$ ). Furthermore, angiosclerosis $(n=10)$, lymphangiectasia $(n=6)$ and a slight non-purulent endometritis $(n=1)$ were detected. These mares ( $\geq 2$ years barren: $n=6$ ) were classified to Category $\|\mathrm{a}(n=4),\| \mathrm{l}(\mathrm{n}=3), \| \mathrm{b}-\mathrm{III}(\mathrm{n}=2)$ and $\| \mathrm{II}(\mathrm{n}=1)$.

Special attention was focused on "periglandular arranged stromal cells" (PSC) in glandular nests with UGD. Some of them encircled affected glands very closely in a dense, "onion skin-like" pattern, whereas the glandular enclosure was more or less complete. An extracellular matrix between the PSC and the basal lamina of the glands could not be detected (Fig. $1 \mathrm{a} / \mathrm{b}$ ). These stromal cells were predominately flat, characterized by slender and long prolongations and small, hyperchromatic nuclei (inactive differentiation). A smaller part of them, mostly grouped on one side of the gland, was oval with large and hypochromatic nuclei (active differentiation; Fig. $1 \mathrm{a} / \mathrm{b})$.

Besides PSC, other stromal cells were arranged loosely/scattered around the glands in a concentric manner with some distance and extracellular matrix between themselves and the glands (Fig. 1 a/b). These "adjacent stromal cells" (ASC) are characterized by a variable (mostly oval) shape with variable prolongations and oval to round nuclei of different size. This study differentiates between PSC, ASC and the stromal cells in the space between the glandular nests, following called "regular arranged stromal cells" (RSC), which were characterized by active or inactive (see above) differentiation in accordance with the stage of the cycle.

The slide levels 1, 6 and 11 (H.-E.-stain) were especially examined regarding changes of the periglandular stroma and the occurrence of PSC and/or ASC in UGD.

Histomorphological findings within the UGD-areas of the different slide-levels

Level 1:

Summarizing the findings of the 3 UGD-groups, $71.08 \%$ of all glandular structures within UGD-areas presented a PSC (Fig. $1 \mathrm{a}$ ), that predominantly $(72.59 \%)$ involved one layer and encircled a quarter (53.89\%), less frequently a half or three-quarter of the particular gland. Complete glandular surrounding (4.06\%) or PSC-multilayers (27.41\%) were found rarely. 
Comparing the groups, the most glands affected could be detected in G2 (92.59\%), followed by G3 (86.06\%). But also $61.04 \%$ of the glands in G1-biopsies showed a PSC. The percentage of a multi-layered attachment of PSC was more frequently found in G2- (45.00\%) and G3-glands (33.48\%) compared to G1 (20.16\%).

Level 6:

Taken the 3 groups together, $73.07 \%$ of all glands within UGD-areas showed a formation of PSC, surrounding a quarter $(47.29 \%)$ or a half $(28.81 \%)$, to a less extend three-quarter of a single gland. In $5.93 \%$ the surrounding was complete. A higher amount (35.00\%) of multi-layered PSC could be found than in level 1.

Comparable to level 1, most of the UGD-glands with PSC could be observed in G2 (89.11\%) and G3 (88.72\%). In G1, $62.69 \%$ of the UGD-glands offered PSC. The multi-layered attachment was comparable between the groups ( $G 1$ : 33.28\%; G2: 34.44\%; G3: 37.29\%).

Level 11:

Totally, $74.18 \%$ of the glands (G1-3) within UGD showed PSC. The percentage of PSC surrounding a quarter, half and three-quarter of the gland was nearly similar to those of level 6. Predominantly $(67.77 \%)$ one layer of PSC could be detected, $32.23 \%$ of the glands presented multi-layers.

Compared to level 1 and 6 a slight increase of PSC-glands within UGD could be detected (Fig. 1 b). The percentage of three-quarter or complete surrounding of PSC was reduced compared to level 6. Most of the multi-layered UGD-glands were found in G3 (37.10\%), compared to those of G1 $(29.54 \%)$ and G2 (27.27\%).

\section{Immunohistochemical findings}

The endometrial epithelial and stromal cells were investigated for their $\alpha$-Actin-, Desmin- and Vimentin-expression. Regarding the stromal cells, RSC (in the unchanged areas of every sample) as well as PSC and ASC (in biopsies/areas with UGD and/or endometrosis) were taken into account. So, PSC and
ASC were summarized and defined as "surrounding stromal cells" (SSC).

Depending on their localization, epithelial cells were subdivided in "regular epithelial cells" (REC) of unaltered glands and the glandular epithelium within UGD-areas (ECUGD) respectively the epithelial cells within endometrotic nests (ECeN).

A diffuse intracytoplasmatic expression of $\alpha$-Actin and Desmin was detectable in stromal cells but not in the glandular epithelium, while both cell populations showed an immunolabelling for $\mathrm{Vi}$ mentin (diffuse, intracytoplasmatic). The number of immunopositive cells as well as the expression-intensity varied (see below).

Percentage data given below regarding to:

(i) unchanged controls: immunopositive locations investigated (10 HPF/slide; mean value), followed by percental data regarding the mean value of immunopositive RSC and/or REC investigated in the $3 \mathrm{SL}$ altogether

(ii) endometrotic controls and UGD-biopsies:

a) immunopositive locations investigated (10 HPF/slide; mean value), followed by percental data regarding the mean value of immunopositive RSC and/or REC investigated in the $3 \mathrm{SL}$ altogether (endometrotic controls) or in every single SL (UGD-biopsies)

b) immunopositive UGD-areas or endometrotic nests in the 3 slide-levels altogether (mean value), followed by percental data regarding the mean value of immunopositive SSC and/or ECeN (endometrosis)/ ECUGD (UGD) in the $3 \mathrm{SL}$ altogether (endometrotic controls) or in every single SL (UGD-biopsies)

Alpha-actin-expression (Tab. 1; slide-level 2, 7, 12)

Independent of the group (controls, UGD), the RSC as well as the SSC (controls with mild endometrosis, UGD-animals) were characterized by an $\alpha$-actin-expression. The percentage of immunolabelled cells and the intensity of expression varied.

\section{Controls without pathological changes}

In nearly all locations investigated the RSC showed an $\alpha$-actin-expression. The number of immunolabelled cells within these

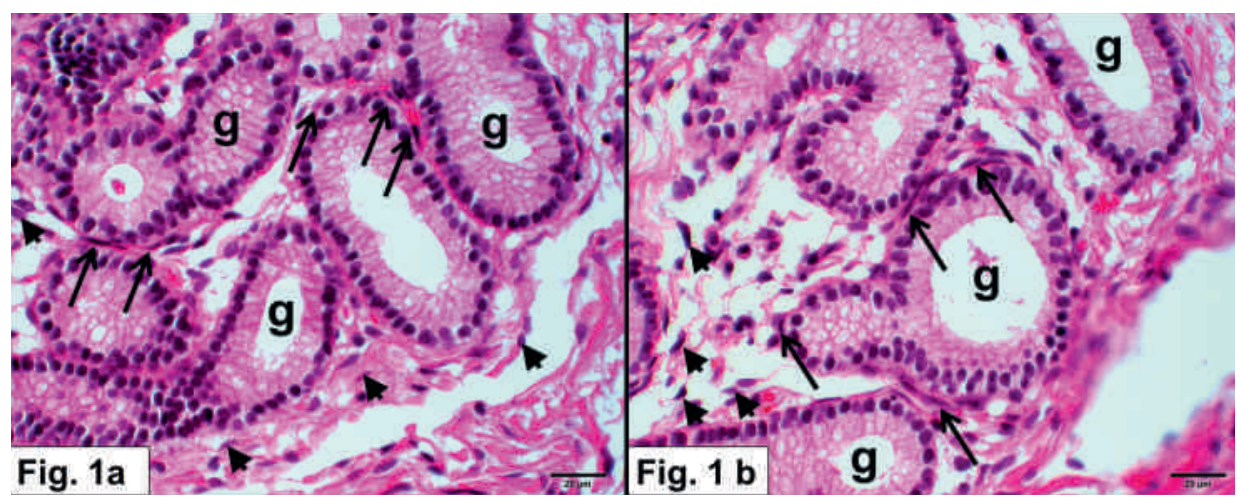

Fig. 1 Within one area of unequal glandular differentiation (UGD) the periglandular stromal cells (PSC, arrows) encircle the uterine glands (g) in an "onion skin-like" pattern. While in slide level 1 (Fig. 1a) the encirclement is limited to one layer of PSC, surrounding about a quarter of numerous glands, in deeper slide levels (Fig. 1b, level 11) of the same area, the glands are encircled by 2 or 3 layers of PSC up to three-quarter of the glands; regular stromal cells (arrowheads); H.-E.-stain. | Innerhalb der UGD-Areale sind die periglandulär angelagerten Stromazellen (PSC, Pfeile) in "zwiebelschalenartigen" Schichten um die Uterindrüsen (g) herum angelagert. Während in Schnittebene 1 (Abb. 1a) zahlreiche Drüsen von einer Schicht PSC zu ungefähr einem Viertel umfasst werden, sind in tieferen Ebenen (Abb. 1b, Ebene 11) desselben Areals die Drüsen maximal zu dreiviertel von 2 oder 3 Schichten PSC umgeben. Reguläre Stromazellen (Pfeilspitzen); H.E.-Färbung. 
locations predominantly represented less than $10 \%$, not exceeding 20\%, whereat the expression-intensity varied (Fig. 2 a).

Controls with mild endometrosis

The RSC and SSC were characterized by an $\alpha$-actin-expression (Fig. 2 c). Comparable to the unchanged endometrium the percentage of immunopositive RSC represented up to $20 \%$, showing an in maximum mild to moderate expression intensity. In contrast, in more than $50 \%$ of the endometrotic nests the number of immunopositive SSC exceeded $40 \%$, occasionally up to $100 \%$. In numerous of these cases an at least moderate $\alpha$-actin-expression could be detected.

\section{UGD}

The results of the RSC in unchanged areas of the biopsies within UGD-endometria resembled those of the endometrot-

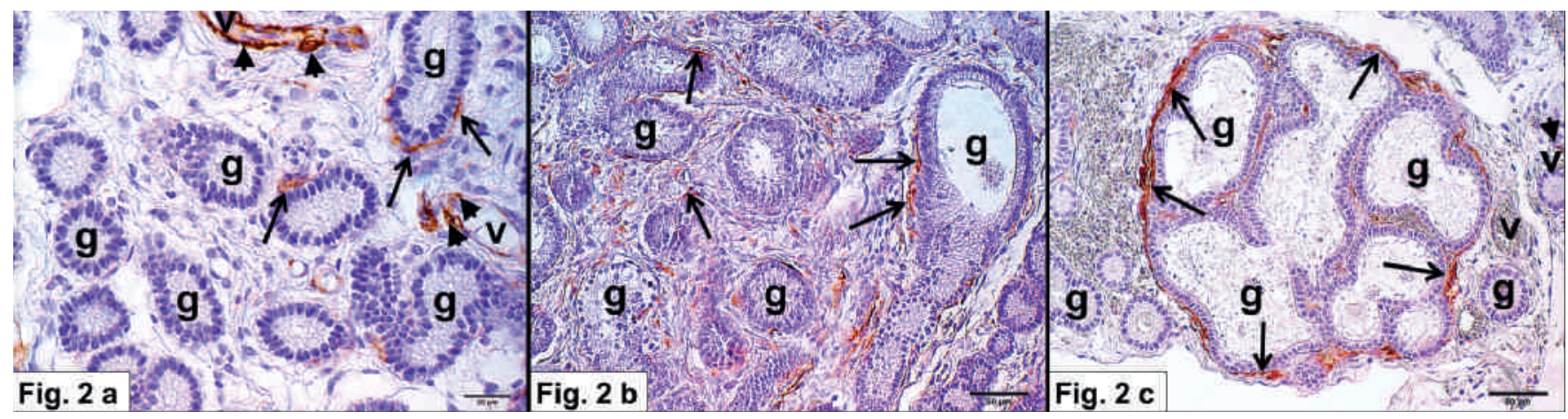

Fig. 2 In the unchanged endometrium (Fig. 2a, control group without alterations), scattered regular arranged stromal cells (RSC, arrows) around the glands (g) show a slight to mild expression of $\alpha$-actin. Within UGD (Fig. 2b), several surrounding stromal cells (SSC, arrows) are characterized by a slight to moderate expression of $\alpha$-actin. Endometrotic areas (Fig. $2 c$, control group with endometrosis) reveal a very intense expression of the microfilament, detectable in nearly all SSC (arrows); venules (v) with moderate to strong expression of $\alpha$-actin in smooth muscle cells (arrowheads); Alpha-actin. | Im unveränderten Endometrium (Abb. 2a, unveränderte Kontrollgruppe) ist um die Drüsen (g) herum eine dezente bis geringgradige $\alpha$-Aktin-Expression in vereinzelten regulären Stromazellen (RSC, Pfeile) zu bemerken. Innerhalb der UGD (Abb. 2b) sind einige Stromazellen (SSC, Pfeile) durch eine dezente bis mittelgradige $\alpha$-Aktin-Expression gekennzeichnet. Endometrosebereiche (Abb. 2c, Kontrollgruppe mit Endometrose) zeigen eine sehr starke Expression des Mikrofilamentes in nahezu allen SSC (Pfeile); Venulen (v) mit mittelgradiger bis starker Expression von $\alpha$-Aktin in glatten Muskelzellen (Pfeilspitzen); Alpha-Aktin.

Table 1 Alpha-Actin-expression in regular arranged (RSC) and surrounding stromal cells (SSC) in the endometrium of the control biopsies (unchanged endometrium; mild endometrosis; each: $n=5)$ in comparison to endometrial biopsies with unequal glandular differentiation (UGD; $\mathrm{n}=23$ ) Alpha-Actin-Expression in regulären (RSC) und umgebenden Stromazellen (SSC) im Endometrium der Kontrollbiopsien (unverändertes Endometrium; geringgradige Endometrose; jeweils: $n=5)$ im Vergleich zu ungleichmäßig differenzierten Endometrien (UGD; $n=23)$

\begin{tabular}{|c|c|c|c|c|c|c|c|c|c|c|c|c|c|c|}
\hline \multirow{3}{*}{$\begin{array}{c}\text { Group } \\
\text { and slide level }\end{array}$} & \multirow{3}{*}{$\mathrm{ICP}$} & \multicolumn{7}{|c|}{ Percentage of (\%) } & \multirow{2}{*}{\multicolumn{6}{|c|}{$\begin{array}{l}\text { Intensity of expression in percentage (\%) } \\
\text { of immunolabelled cells in ipN/L }\end{array}$}} \\
\hline & & \multirow{2}{*}{$\mathrm{ipN} / \mathrm{L}^{4}$} & \multicolumn{6}{|c|}{ Immunolabelled cells in ipN/L } & & & & & & \\
\hline & & & $\leq 10$ & $11-20$ & $21-40$ & $41-50$ & $51-80$ & $81-100$ & $(+)$ & + & $+(+)$ & ++ & $++(+)$ & +++ \\
\hline $\begin{array}{c}\text { EUC } \\
(S L 2,7,12)^{1,2,3}\end{array}$ & RSC & 86.67 & 76.92 & 23.08 & 0 & 0 & 0 & 0 & 23.08 & 38.46 & 38.46 & 0 & 0 & 0 \\
\hline UGD SL $2^{1}$ & RSC & 98.04 & 96.00 & 3.00 & 0 & 0 & 1.00 & 0 & 32.00 & 47.00 & 20.00 & 1.00 & 0 & 0 \\
\hline UGD SL 71 & RSC & 100.00 & 97.06 & 1.96 & 0.98 & 0 & 0 & 0 & 30.39 & 50.00 & 17.65 & 1.96 & 0 & 0 \\
\hline UGD SL $12^{1}$ & RSC & 96.08 & 97.96 & 2.04 & 0 & 0 & 0 & 0 & 28.57 & 51.02 & 20.41 & 0 & 0 & 0 \\
\hline UGD SL $2^{1}$ & SSC & 97.18 & 47.83 & 27.54 & 7.25 & 8.70 & 8.70 & 0 & 18.84 & 50.72 & 11.59 & 15.94 & 2.90 & 0 \\
\hline UGD SL 71 & SSC & 97.18 & 42.03 & 36.23 & 8.70 & 2.90 & 8.70 & 1.45 & 26.09 & 31.88 & 14.49 & 20.29 & 5.80 & 1.45 \\
\hline UGD SL 12' & SSC & 97.14 & 33.82 & 41.18 & 10.29 & 2.94 & 5.88 & 5.88 & 29.41 & 26.47 & 10.29 & 29.41 & 4.41 & 0 \\
\hline EEM & RSC & 100.00 & 86.67 & 13.33 & 0 & 0 & 0 & 0 & 20.00 & 33.33 & 46.67 & 0 & 0 & 0 \\
\hline$(S L 2,7,12)^{1,2,4}$ & SSC & 100.00 & 16.67 & 19.05 & 9.52 & 16.67 & 26.19 & 11.90 & 14.29 & 30.95 & 14.29 & 21.43 & 11.90 & 7.14 \\
\hline
\end{tabular}

EUC: unchanged endometrium; EEM: Endometrium with mild endometrosis; ICP: investigated cell population; SL: slide level; ipN/L: percentage of immunopositive nests (UGD/endometrosis) or locations per $10 \mathrm{HPF}$ (unchanged areas); ${ }^{1}$ number of the investigated level out of 19 serial slides; ${ }^{2}$ mean value of all three levels; ${ }^{3}$ no SSC in these biopsies; ${ }^{4}$ regarding the investigated cell population (RSC/SSC) | EUC: unverändertes Endometrium; EEM: Endometrium mit geringgradiger Endometrose; ICP: ausgewertete Zellpopulation; SL: Schnittebene; ipN/L: Prozentsatz positiver Nester (UGD/Endometrose) oder unveränderter Areale pro 10 HPF; ${ }^{7}$ Ausgewertete Schnittebene der 19 Serienschnitte; ${ }^{2}$ Durchschnittswert aller 3 ausgewerteten Schnittebenen; ${ }^{3}$ keine SSC in diesen Biopsien; ${ }^{4}$ Betrachtung der ausgewerteten Zellpopulation (RSC/SSC) 
ic controls, the SSC of the latter and the SSC of nearly all UGD-areas expressed $\alpha$-actin. In at least $75 \%$ of the UGD-areas maximally $20 \%$ of the SSC showed a predominantly slight or mild expression (Fig. 2 b). Nevertheless, some areas offered a higher number of immunolabelled SSC and a stronger expression-intensity.

Comparing the different slide-levels, the percentage of immunolabelled SSC increased slightly in slide 7 and 12, while the expression-intensity was quite variable.

Desmin-expression (Tab. 2; slide-level: 3, 8, 13)

Independent of the group (controls, UGD-animals), the RSC as well as the SSC expressed desmin. The percentage and intensity of immunolabelled cells varied.

\section{Controls without pathological changes}

Predominantly between $1 \%$ and $20 \%$ of the RSC in nearly all HPFs investigated showed a desmin-expression, which was of variable, but frequently moderate intensity (Fig. 3 a).

Controls with mild endometrosis

The desmin-expression of RSC resembled the one of the unchanged endometrium. The expression-intensity was slightly reduced (frequently mild). In comparison to the RSC in unchanged controls and UGD-slides, nearly all endometrotic nests possessed an increased percentage of immunopositive SSC, often exceeding 50\% (Fig. 3 c). The expression-intensity was quite variable but slightly reduced in SSC.

\section{UGD}

The desmin expression in RSC of numerous unchanged areas mostly resembled those of the controls but the expression-intensity was weaker.

A variable number of SSC in numerous UGD-areas showed a desmin-expression (Fig. 3 b). As in endometrotic controls, the number of immunolabelled SSC increased in comparison to the RSC of unchanged areas and controls. The expression-intensity rarely exceeded mild to moderate.

Comparing the SL, a reduced percentage of UGD-areas expressing desmin in level 13 and 8 assimilable to level 3 was found. Also in level 13 more nests showed a slight expression-intensity than in level 8 and 3.

Vimentin-expression (Tab. 3; slide-level: 4, 9, 14)

Independent of the group (controls, UGD-animals), the RSC and SSC expressed vimentin. But the immunolabelling (per-

Table 2 Desmin-expression in regular arranged (RSC) and surrounding stromal cells (SSC) in the endometrium of the control biopsies (unchanged endometrium; mild endometrosis; each: $n=5)$ in comparison to endometrial biopsies with unequal glandular differentiation (UGD; $n=23$ ) Desmin-Expression in regulären (RSC) und umgebenden Stromazellen (SSC) im Endometrium der Kontrollbiopsien (unverändertes Endometrium; geringgradige Endometrose; jeweils: $n=5$ ) im Vergleich zu ungleichmäßig differenzierten Endometrien (UGD; $n=23$

\begin{tabular}{|c|c|c|c|c|c|c|c|c|c|c|c|c|c|c|}
\hline \multirow{3}{*}{$\begin{array}{l}\text { Group and } \\
\text { slide level }\end{array}$} & \multirow{3}{*}{$\mathrm{ICP}$} & \multicolumn{7}{|c|}{ Percentage of (\%) } & \multirow{2}{*}{\multicolumn{6}{|c|}{$\begin{array}{l}\text { Intensity of expression in percentage (\%) } \\
\text { of immunolabelled cells in ipN/L }\end{array}$}} \\
\hline & & \multirow{2}{*}{$\mathrm{ipN} / \mathrm{L}^{4}$} & \multicolumn{6}{|c|}{ Immunolabelled cells in ipN/L } & & & & & & \\
\hline & & & $\leq 10$ & $11-20$ & $21-40$ & $41-50$ & $51-80$ & $81-100$ & $(+)$ & + & $+(+)$ & ++ & $++(+)$ & +++ \\
\hline $\begin{array}{c}\text { EUC } \\
(\mathrm{SL} 3,8,13)^{1,2,3}\end{array}$ & RSC & 93.33 & 25.00 & 35.71 & 17.86 & 10.71 & 10.71 & 0 & 0 & 17.86 & 28.57 & 46.43 & 3.57 & 3.57 \\
\hline UGD SL $3^{1}$ & RSC & 89.13 & 36.59 & 12.20 & 29.27 & 4.88 & 4.88 & 4.88 & 4.88 & 53.66 & 24.39 & 12.20 & 2.44 & 2.44 \\
\hline UGD SL $8^{1}$ & RSC & 86.96 & 32.50 & 15.00 & 12.50 & 30.00 & 5.00 & 5.00 & 5.00 & 47.50 & 30.00 & 12.50 & 2.50 & 2.50 \\
\hline UGD SL $13^{1}$ & RSC & 89.13 & 24.39 & 24.39 & 21.95 & 12.20 & 17.07 & 0 & 2.44 & 39.02 & 41.46 & 14.63 & 0.00 & 2.44 \\
\hline UGD SL $3^{1}$ & SSC & 97.10 & 25.37 & 14.93 & 7.46 & 10.45 & 35.82 & 5.97 & 7.46 & 53.73 & 20.90 & 14.93 & 1.49 & 1.49 \\
\hline UGD SL $8^{1}$ & SSC & 92.75 & 17.19 & 10.94 & 15.63 & 21.88 & 32.81 & 1.56 & 17.19 & 48.44 & 23.44 & 10.94 & 0 & 0 \\
\hline UGD SL $13^{1}$ & SSC & 86.76 & 11.86 & 8.47 & 18.64 & 18.64 & 35.59 & 6.78 & 20.34 & 38.98 & 25.42 & 10.17 & 5.08 & 0 \\
\hline & RSC & 86.67 & 38.46 & 23.08 & 3.85 & 15.38 & 19.23 & 0 & 3.85 & 42.31 & 19.23 & 23.08 & 11.54 & 0 \\
\hline (SL 3,8, & SSC & 97.62 & 17.07 & 2.44 & 17.07 & 14.63 & 39.02 & 9.76 & 29.27 & 19.51 & 21.95 & 24.39 & 4.88 & 0 \\
\hline
\end{tabular}

EUC: unchanged endometrium; EEM: Endometrium with mild endometrosis; ICP: investigated cell population; SL: slide level; ipN/L: percentage of immunopositive nests (UGD/endometrosis) or locations per $10 \mathrm{HPF}$ (unchanged areas); 'number of the investigated level out of 19 serial slides; ${ }^{2}$ mean value of all three levels; ${ }^{3}$ no SSC in these biopsies; ${ }^{4}$ regarding the investigated cell population (RSC/SSC) | EUC: unverändertes Endometrium; EEM: Endometrium mit geringgradiger Endometrose; ICP: ausgewertete Zellpopulation; SL: Schnittebene; ipN/L: Prozentsatz positiver Nester (UGD/Endometrose) oder unveränderter Areale pro 10 HPF; 'Ausgewertete Schnittebene der 19 Serienschnitte; ${ }^{2}$ Durchschnittswert aller 3 ausgewerteten Schnittebenen; ${ }^{3}$ keine SSC in diesen Biopsien; ${ }^{4}$ Betrachtung der ausgewerteten Zellpopulation (RSC/SSC) 
centage and intensity) of epithelial cells was variable within the different groups.

\section{Controls without pathological changes}

In the RSC of all locations investigated, a variable vimentin-expression could be detected that was predominantly (21 to $80 \%$ of the RSC) in maximum moderate. In contrast, none of the regular epithelial cells (REC, Fig. 4 a) showed an immunolabelling.
Controls with mild endometrosis

In nearly all of the unchanged areas examined, a vimentin-expression by RSC could be observed, while the percentage of immunolabelled RSC was quite variable. In comparison to the unchanged endometrial samples there were more areas that showed either less than $20 \%$ or more than $81 \%$ immunopositive RSC. The expression-intensity resembled those of the unchanged endometria.

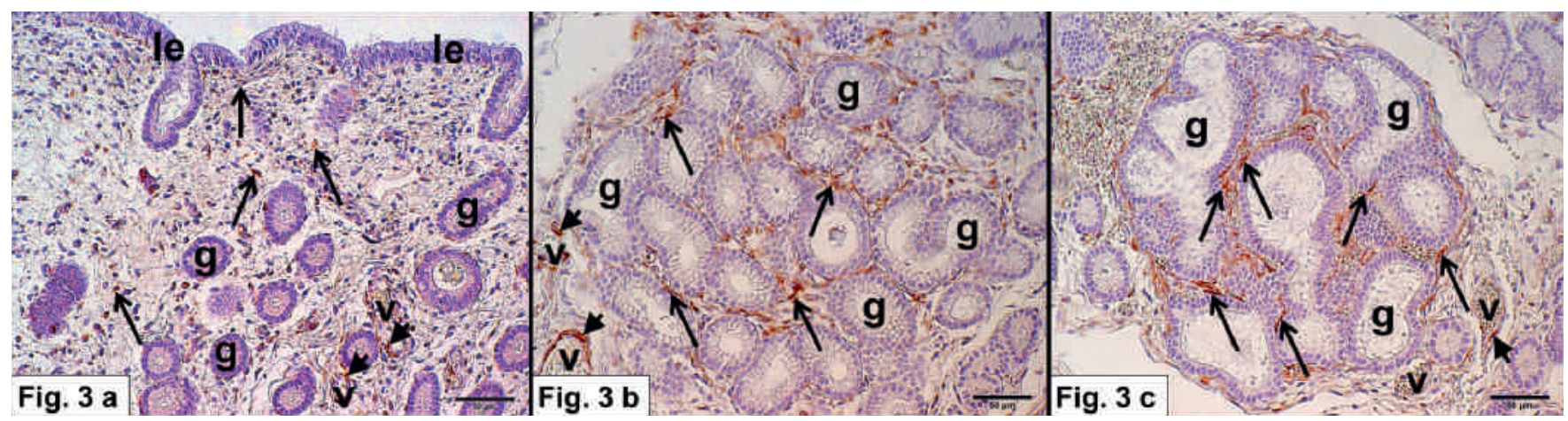

Fig. 3 In the unchanged endometrium (Fig. 3a, control group without alterations), single regular arranged stromal cells (RSC, arrows) around the glands (g) show a moderate expression of desmin. Within UGD (Fig. 3b), the desmin-expression is characterized by a slight to mild expression in numerous surrounding stromal cells (SSC, arrows). Endometrotic areas (Fig. 3c, control group with endometrosis) reveal a mild to moderate expression of the intermediate filament, detectable in the bigger part of the SSC (arrows); venules (v) with several smooth muscle cells expressing desmin with mild to moderate intensity (arrowheads); luminal epithelium (le); Desmin. I Im unveränderten Endometrium (Abb. 3a, unveränderte Kontrollgruppe) sind einzelne reguläre Stromazellen (RSC, Pfeile) um die Drüsen (g) herum durch eine mittelgradige Desmin-Expression gekennzeichnet. Zahlreiche Stromazellen innerhalb der UGD (Abb. 3b, SSC, Pfeile) weisen eine dezente bis geringgradige Expression von Desmin auf. Endometroseareale (Abb. 3c, Kontrollgruppe mit Endometrose) zeigen im Großteil der SSC (Pfeile) eine gering-bis mittelgradige Expression des Intermediärfilamentes; Venulen (v) mit einigen glatten Muskelzellen, die Desmin mit gering- bis mittelgradiger Intensität (Pfeilspitzen) exprimieren; luminales Epithel (le); Desmin.

Table 3 a Vimentin-expression in regular arranged (RSC) and surrounding stromal cells (SSC) in the endometrium of the control biopsies (unchanged endometrium; mild endometrosis; each: $n=5)$ in comparison to endometrial biopsies with unequal glandular differentiation (UGD; $\mathrm{n}=23$ ) Vimentin-Expression in regulären (RSC) und umgebenden Stromazellen (SSC) im Endometrium der Kontrollbiopsien (unverändertes Endometrium; geringgradige Endometrose; jeweils: $n=5$ ) im Vergleich zu ungleichmäßig differenzierten Endometrien (UGD; $n=23$ )

\begin{tabular}{|c|c|c|c|c|c|c|c|c|c|c|c|c|c|c|}
\hline \multirow{3}{*}{$\begin{array}{l}\text { Group and } \\
\text { slide level }\end{array}$} & \multirow{3}{*}{$\mathrm{ICP}$} & \multicolumn{7}{|c|}{ Percentage of (\%) } & \multirow{2}{*}{\multicolumn{6}{|c|}{$\begin{array}{l}\text { Intensity of expression in percentage (\%) } \\
\text { of immunolabelled cells in ipN/L }\end{array}$}} \\
\hline & & \multirow{2}{*}{$\mathrm{ipN} / \mathrm{L}^{4}$} & \multicolumn{6}{|c|}{ Immunolabelled cells in ipN/L } & & & & & & \\
\hline & & & $\leq 10$ & $11-20$ & $21-40$ & $41-50$ & $51-80$ & $81-100$ & $(+)$ & + & $+(+)$ & ++ & $++(+)$ & +++ \\
\hline $\begin{array}{c}\text { EUC } \\
(\mathrm{SL} 4,9,14)^{1,2,3,4}\end{array}$ & RSC & 100.00 & 6.67 & 6.67 & 30.00 & 16.67 & 33.33 & 6.67 & 13.33 & 30.00 & 10.00 & 30.00 & 10.00 & 6.67 \\
\hline UGD SL $4^{1}$ & $\mathrm{RSC}$ & 89.13 & 14.63 & 36.59 & 7.32 & 14.63 & 19.51 & 7.32 & 21.95 & 43.90 & 12.20 & 17.07 & 2.44 & 2.44 \\
\hline UGD SL $9^{1}$ & RSC & 89.13 & 14.63 & 17.07 & 21.95 & 9.76 & 29.27 & 7.32 & 12.20 & 26.83 & 26.83 & 21.95 & 7.32 & 4.88 \\
\hline UGD SL $14^{1}$ & RSC & 89.13 & 7.32 & 24.39 & 29.27 & 9.76 & 12.20 & 17.07 & 7.32 & 46.34 & 19.51 & 9.76 & 9.76 & 7.32 \\
\hline UGD SL $4^{1}$ & SSC & 95.65 & 6.06 & 10.61 & 13.64 & 9.09 & 37.88 & 22.73 & 16.67 & 31.82 & 13.64 & 19.70 & 15.15 & 3.03 \\
\hline UGD SL $9^{1}$ & SSC & 94.20 & 4.62 & 9.23 & 7.69 & 9.23 & 32.31 & 36.92 & 9.23 & 27.69 & 13.85 & 23.08 & 18.46 & 7.69 \\
\hline UGD SL $14^{1}$ & SSC & 92.75 & 14.06 & 7.81 & 9.38 & 9.38 & 28.13 & 31.25 & 25.00 & 17.19 & 17.19 & 18.75 & 20.31 & 1.56 \\
\hline EEM & RSC & 96.67 & 17.24 & 13.79 & 10.34 & 17.24 & 13.79 & 27.59 & 20.69 & 17.24 & 6.90 & 34.48 & 13.79 & 6.90 \\
\hline$(S L 4,9,14)^{1,2,4}$ & SSC & 90.48 & 13.16 & 5.26 & 21.05 & 7.89 & 13.16 & 39.47 & 31.58 & 26.32 & 13.16 & 7.89 & 13.16 & 7.89 \\
\hline
\end{tabular}

EUC: unchanged endometrium; EEM: Endometrium with mild endometrosis; ICP: investigated cell population; SL: slide level; ipN/L: percentage of immunopositive nests (UGD/endometrosis) or locations per $10 \mathrm{HPF}$ (unchanged areas); ${ }^{1}$ number of the investigated level out of 19 serial slides; ${ }^{2}$ mean value of all three levels; ${ }^{3}$ no SSC in these biopsies; ${ }^{4}$ regarding the investigated cell population (RSC/SSC) | EUC: unverändertes Endometrium; EEM: Endometrium mit geringgradiger Endometrose; ICP:

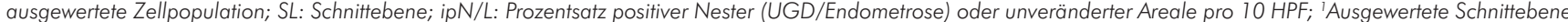
der 19 Serienschnitte; ${ }^{2}$ Durchschnittswert aller 3 ausgewerteten Schnittebenen; ${ }^{3}$ keine SSC in diesen Biopsien; ${ }^{4}$ Betrachtung der ausgewerteten Zellpopulation (RSC/SSC) 
Nearly all the endometrotic nests contained SSC expressing vimentin. Frequently, they showed $81-100 \%$ of immunolabelled cells, that were predominantly of in maximum mild expression-intensity (Fig. 4 c).

Contrary to the unchanged endometrium, some of the investigated locations offered a mild or moderate vimentin-expression by up to $10 \%$ of the REC. Moreover, the majority of the endometrotic nests expressed vimentin frequently strong in up to $40 \%$ of the epithelial cells within endometrotic nests (ECeN).

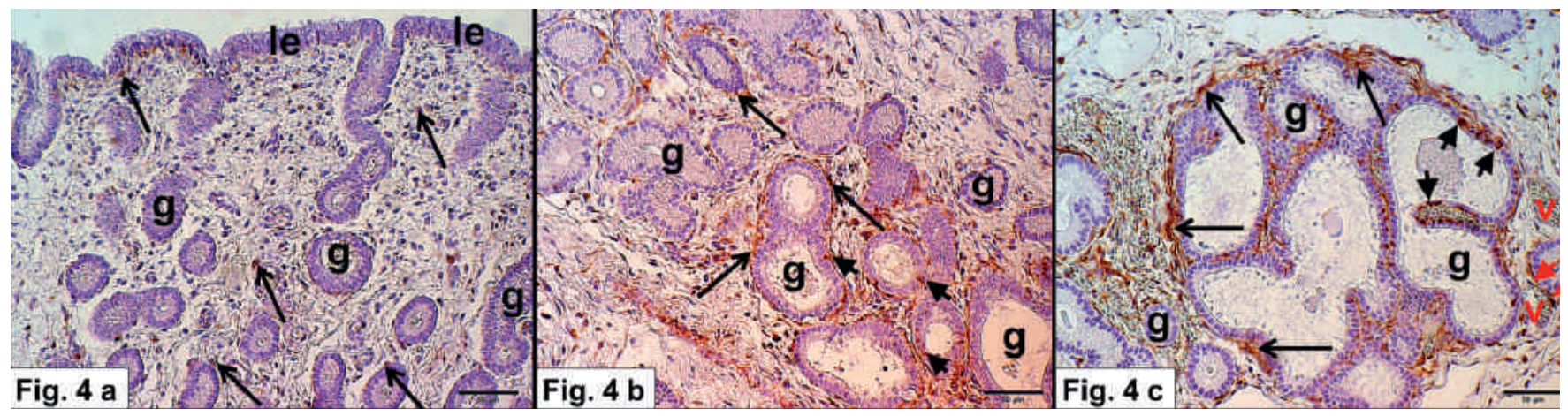

Fig. 4 In the unchanged endometrium (Fig. 4a, control group without alterations), some regular arranged stromal cells (RSC, arrows) around the glands (g) show a slight to mild expression of vimentin. The glandular and luminal epithelium (le) does not express vimentin. Within UGD (Fig. 4b), the vimentin-expression is characterized by a moderate expression in the bigger part of surrounding stromal cells (SSC, arrows), while few glandular epithelial cells (GEC, arrowheads) present an at least moderate expression. Endometrotic areas (Fig. 4c, control group with endometrosis) reveal a moderate to strong expression of the intermediate filament, detectable in the bigger part of the SSC (arrows). Some GEC show a strong vimentin-expression (arrowheads); smooth muscle cells and endothelial cells of venules (v) expressing vimentin (red arrowheads); Vimentin. I Im unveränderten Endometrium (Abb. 4a, unveränderte Kontrollgruppe) zeigen einige reguläre Stromazellen (RSC, Pfeile) um die Drüsen (g) eine dezente bis geringgradige Vimentin-Expression. Glanduläre und luminale Epithelien (le) exprimieren kein Vimentin. In der UGD (Abb. 4b) ist der Großteil der Stromazellen (SSC, Pfeile) durch eine mittelgradige Vimentin-Expression charakterisiert, während einzelne glanduläre Epithelzellen (GEC, Pfeile) eine mindestens mittelgradige Expression zeigen. Eine moderate bis starke Expression des Intermediärfilamentes kann in einem Großteil der SSC (Pfeile) in Endometrosearealen (Abb. 4c, Kontrollgruppe mit mittelgradiger Endometrose) beobachtet werden. Einige GEC zeigen eine starke Vimentin-Expression (Pfeile); glatte Muskelzellen und Endothelzellen von Venulen (v) exprimieren Vimentin (rote Pfeilspitzen); Vimentin.

Table 3 b Vimentin-expression in regular epithelial cells (REC), epithelial cells within UGD (ECUGD) and epithelial cells within endometrotic nests $(E C e N)$ in the endometrium of the control biopsies (unchanged endometrium; mild endometrosis; each: $n=5)$ in comparison to endometrial biopsies with unequal glandular differentiation (UGD; $\mathrm{n}=23$ ) | Vimentin-Expression in regulären Epithelzellen (REC), Epithelzellenin in der UGD (ECUGD) bzw. der Endometrose $(E C e N)$ im Endometrium der Kontrollbiopsien (unverändertes Endometrium; Endometrium mit geringgradiger Endometrose; jeweils: $n=5)$ im Vergleich mit ungleichmäßig glandulär differenzierten Endometrien (UGD; $n=23$ )

\begin{tabular}{|c|c|c|c|c|c|c|c|c|c|c|c|c|c|c|}
\hline \multirow{3}{*}{$\begin{array}{l}\text { Group and } \\
\text { slide level }\end{array}$} & \multirow{3}{*}{$I C P$} & \multicolumn{7}{|c|}{ Percentage of (\%) } & \multirow{2}{*}{\multicolumn{6}{|c|}{$\begin{array}{l}\text { Intensity of expression in percentage (\%) } \\
\text { of immunolabelled cells in ipN/L }\end{array}$}} \\
\hline & & \multirow{2}{*}{$\mathrm{ipN} / \mathrm{L}^{4}$} & \multicolumn{6}{|c|}{ Immunolabelled cells in ipN/L } & & & & & & \\
\hline & & & $\leq 10$ & $11-20$ & $21-40$ & $41-50$ & $51-80$ & $81-100$ & $(+)$ & + & $+(+)$ & ++ & $++(+)$ & +++ \\
\hline $\begin{array}{c}\text { EUC } \\
(\mathrm{SL} 4,9,14)^{1,2,3,4}\end{array}$ & REC & 0 & 0 & 0 & 0 & 0 & 0 & 0 & 0 & 0 & 0 & 0 & 0 & 0 \\
\hline UGD SL $4^{1}$ & REC & 21.74 & 100.00 & 0 & 0 & 0 & 0 & 0 & 0 & 0 & 40.00 & 40.00 & 0 & 20.00 \\
\hline UGD SL $9^{1}$ & REC & 26.09 & 100.00 & 0 & 0 & 0 & 0 & 0 & 16.67 & 0 & 50.00 & 33.33 & 0 & 0 \\
\hline UGD SL $14^{1}$ & REC & 30.43 & 100.00 & 0 & 0 & 0 & 0 & 0 & 0 & 28.57 & 42.86 & 14.29 & 14.29 & 0 \\
\hline UGD SL $4^{1}$ & ECUGD & 30.43 & 95.24 & 4.76 & 0 & 0 & 0 & 0 & 0 & 14.29 & 19.05 & 28.57 & 4.76 & 33.33 \\
\hline UGD SL 9י1 & ECUGD & 39.13 & 85.19 & 14.81 & 0 & 0 & 0 & 0 & 3.70 & 11.11 & 25.93 & 14.81 & 14.81 & 29.63 \\
\hline UGD SL $14^{1}$ & ECUGD & 26.47 & 88.89 & 11.11 & 0 & 0 & 0 & 0 & 5.56 & 0 & 27.78 & 27.78 & 33.33 & 5.56 \\
\hline \multirow{2}{*}{$\begin{array}{c}\text { EEM } \\
(S L 4,9,14)^{1,2,4}\end{array}$} & REC & 20.00 & 100.00 & 0 & 0 & 0 & 0 & 0 & 0 & 33.33 & 33.33 & 33.33 & 0 & 0 \\
\hline & $\mathrm{ECeN}$ & 52.38 & 59.09 & 31.82 & 9.09 & 0 & 0 & 0 & 4.55 & 4.55 & 0 & 27.27 & 18.18 & 45.45 \\
\hline
\end{tabular}

EUC: unchanged endometrium; EEM: Endometrium with mild endometrosis; ICP: investigated cell population; SL: slide level; ipN/L: percentage of immunopositive nests (UGD/endometrosis) or locations per $10 \mathrm{HPF}$ (unchanged areas); ${ }^{1}$ number of the investigated level out of 19 serial slides; ${ }^{2}$ mean value of all three levels; ${ }^{3}$ no ECUGD/ ECeN in these biopsies; ${ }^{4}$ regarding the investigated cell population (REC/ECUGD/ECeN) | EUC: unverändertes Endometrium; EEM: Endometrium mit geringgradiger Endometrose; ICP: ausgewertete Zellpopulation; SL: Schnittebene; ipN/L: Prozentsatz positiver Nester (UGD/Endometrose) oder unveränderter Areale pro 10 HPF; 'Ausgewertete Schnittebene der 19 Serienschnitte; ${ }^{2}$ Durchschnittswert aller 3 ausgewerteten Schnittebenen; ${ }^{3}$ keine ECUGD/ECeN in diesen Biopsien; ${ }^{4}$ Betrachtung der ausgewerteten Zellpopulation (REC/EGUGD/ECeN) 
quite variable in the different slide-levels, the expression-intensity predominantly ranged between mild and moderate.

In nearly all UGD-areas a vimentin-expression occured in frequently $51-80 \%$ or $81-100 \%$ of the SSC. Compared to the RSC, a higher number of the immunolabelled SSC were characterized by a moderate to strong expression-intensity.

No distinctive differences could be found regarding the expression-behaviour of the SSC in the different slide-levels (Fig. 4 b).

A vimentin-expression was seen in less than $10 \%$ of the REC of several UGD-slides. The intensity varied slightly but was predominantly in maximum moderate.

Comparable to the findings within endometrotic controls, an expression of vimentin could be found in the epithelium (ECUGD) within about $1 / 3$ of the areas investigated. The immunolabelling of in maximum $20 \%$ of the ECUGD was mostly weaker compared to the $\mathrm{ECeN}$ of the endometrotic samples (Fig. 4 b).

Regarding the expression-behaviour of the ECUGD in the different slide-levels, no distinctive differences could be found.

\section{Discussion}

Maldifferentiations as UGD are not included but listed as separate diagnoses in the categorization scheme for endometrial tissue by Kenney and Doig (1986), modified by Schoon et al. (1992, 1997). So, UGD does not influence the prognosis of fertility although it is assumed to result from a local damage of endometrial hormone receptors and therefore causes a hormonal dysfunction (Schoon et al. 1999 Häfner et al. 2001).

As the only difference between both alterations is the periglandular and/or stromal fibrosis in endometrosis that is not definitely detectable in deeper SL of the investigated biopsies in this study, it can be excluded that UGD is a margin cut of endometrosis. However, a distinct PSC within UGD-areas could be detected, that mostly consisted of one cell-layer and covered only a quarter of the affected gland. To the authors knowledge this is the first description of a PSC in UGD that was not observable in the unchanged controls, so this maintains the theory that UGD is an early stage of endometrosis.

The immunohistochemical investigation of UGD should support this assumption, as the expression of the investigated proteins ( $\alpha$-actin, desmin, vimentin) is well known in both the unchanged endometrium (Aupperle et al. 2004, Aupperle et al. 2000, Raila 2000, Brunckhorst et al. 1991) and in endometrosis (Hoffmann 2006, Raila 2000, Walter et al. 2001). The present study was done to compare the expression-behaviour of unchanged endometrium, endometrosis and UGD, but also to demonstrate the approach of the expression in UGD on the one in endometrosis.

According to Walter et al. (2001), a-actin is sensitive for the detection of horses with a predisposition for endometrosis be- cause it is not expressed in unchanged endometrium (Raila 2000). But already stromal cells in mild endometrosis (Raila 2000, Walter et al. 2001, Hoffmann 2006) are known to express $\alpha$-actin.

The results of the own study are mainly in line with those of the mentioned authors, as numerous SSC within endometrosis are characterized by a distinctive expression of $\alpha$-actin. Comparable to the results of Walter et al. (2001), who noted some $\alpha$-actin-positive "fibrocytes" in the unchanged areas (stratum compactum) of endometrotic biopsies and sometimes closely around inconspicuous glands, the endometrotic samples of the own study as well as the unchanged controls showed scattered immunopositive RSC. This differs from Raila (2000), who did not see an $\alpha$-actin-expression in unchanged endometria. These different findings are possibly due to different immunohistochemical techniques or the collection of some biopsies used in the study of Raila (2000) probably in winter anoestrus.

Summing up, in the own study the unchanged areas of the controls are characterized by an $\alpha$-actin-expression in single RSC, regularly not exceeding mild to moderate intensity. This also is found in RSC of the UGD-biopsies, while numerous of the SSC within endometrosis express the protein even with moderate or strong intensity. Within UGD-areas, the number of immunopositive SSC as well as the staining intensity is clearly increased compared to the RSC. Although the difference is not as strong as in endometrosis, a clear tendency towards endometrosis can be detected.

As Walter et al. (2001) concluded for endometrotic areas, the expression of periglandular stromal cell in UGD indicates a myofibroblastic differentiation of these cells. This is a significant sign of some stromal cells in equine endometrosis. According to Raila (2000), the contractile attributes of myofibroblasts are responsible for dilatation of fibrotic glands (Schoon et al. 1993).

According to Raila (2000) and Aupperle et al. (2004) a desmin expression is not observable in equine endometria under physiological conditions. In the present study, several RSC of the control mares showed a maximally moderate expression of desmin. Contrary, Aupperle et al. (2004) detected a desmin-expression in several (unchanged) stromal cells outside of fibrotic nests in single mares with moderate to severe endometrosis. Maybe this is explainable because some of Aupperle's biopsies were taken outside the physiological breeding season. In Raila's study, there is no further information from which season the samples originate.

Within endometrosis, the percentage of desmin expressing SSC increased while the expression intensity was slightly reduced compared to the RSC. Raila (2000) found stromal cells expressing desmin in moderate to strong but not in mild endometrosis while Hoffmann (2006) detected a very variable expression of desmin in endometrotic stromal cells. The latter classified the biopsies according to the character (active/inactive destructing/not destructing endometrosis) but not to the degree of endometrosis. Walter et al. (2001) and Aupperle et al. (2004) saw only a few desmin expressing periglandular fibroblasts within endometrotic tissue. 
The percentage of desmin positive SSC in UGD-areas varies but altogether is increased compared to the RSC within UGD-biopsies. As also detectable in endometrosis, the expression intensity is lower in SSC within UGD compared to those of the RSC. These results partially resemble those of Aupperle et al. (2003) in mares with moderate to severe endometrosis. Häfner (1999) also saw a decrease of the desmin expression within stromal cells in UGD-areas in unequal proliferative differentiated endometria.

The variable but slightly reduced expression intensity detected in UGD as well as in endometrotic areas of this study supports UGD being an early stage of endometrosis. Also, the simultaneous expression of desmin and vimentin (see below) indicates a myofibroblastic differentiation of the affected stromal cells as already mentioned for an $\alpha$-actin-expression.

In accordance with Aupperle et al. (2004) and Häfner (1999), the REC in unchanged control mares of the own study did not express vimentin at all. But few REC in unaltered glands of some control mares with endometrosis expressed vimentin. In the study of Aupperle et al. (2004), single pathological inactive differentiated endometria showed a vimentin-expression in epithelial cells. The biopsies of this study originate from active cycling mares, so inactivity does not explain the expression of vimentin in REC.

A variable vimentin-expression in unchanged stromal cells (Häfner 1999) could also be detected in the RSC of the own study. In contrast, Aupperle et al. (2004) saw an intense expression of vimentin in nearly all stromal cells (healthy as well as fibrotic). Hoffmann (2006) detected a strong vimentin-expression of stromal cells in all types of endometrosis. In the present study, the percentage of immunolabelled SSC within endometrosis is higher but the intensity is reduced compared to the RSC. This fits to the findings of Hoffmann (2006) and Aupperle et al. (2004) regarding especially the intensity.

Consistent with Aupperle et al. (2004), who saw a rising percentage of epithelial vimentin-expression in accordance with the degree of endometrosis, more than half of the fibrotic nests of the present study showed a variable expression of vimentin in a few ECeN. Aupperle et al. (2004) supposed that epithelial vimentin-expression should stabilize the cell. Most of the mares examined by Hoffmann (2006) showed a variable expression of vimentin in epithelial cells within fibrotic nests that was slightly more intense in destructing endometrosis.

Häfner (1999) noticed an intense expression of vimentin in more than half of the unchanged stromal cells of unequal proliferative differentiated biopsies. In densely arranged areas, all stromal cells expressed vimentin while percentage and intensity were reduced in "glandular nests" (UGD). This is comparable to the own study as the percentage of immunopositive SSC increased in UGD and in endometrosis while the expression intensity was slightly reduced towards the RSC. This similar pattern of vimentin-expression indicates that UGD is an early form of endometrosis.

A strong tendency towards the results in endometrosis can also be seen as several ECUGD presented a variable vimen- tin-expression. Aupperle et al. (2004) described this for fibrotic glands according to the degree of endometrosis. It is remarkable that most of the ECUGD in the present study expressed vimentin with a moderate to strong intensity, as also visible in ECeN. Regarding this, the results of UGD-biopsies show an approach towards endometrosis.

Aupperle et al. (2004) discussed the epithelial vimentin-expression within endometrosis to originate from hypoxia or oxidative stress based on periglandular fibrosis.

Summing up the results of this study, it is more probable that UGD is an early stage of endometrosis than a separate lesion. Therefore, the hypotheses supposed for the pathogenesis of endometrosis should also apply for UGD.

According to Skalli et al. (1989) and Sappino et al. (1990), the expression of different micro- and intermediate filaments (vimentin-expression or coexpression with desmin and/or $\alpha$-actin) in stromal cells is a sign of increasing myofibroblastic maturation which is found in tissue fibroses amongst others.

Primary changes in stromal cells and myofibroblastic differentiation could cause changes in the spectrum of growth factors and mediators expressed by them. The arrangement of myofibroblasts around glands separates the glands from oxygen-diffusion and paracrine secretions, therefore it results in under-supply and hypoxia of epithelial cells postulated by Aupperle et al. (2004) in the wake of endometrosis.

As Brenner et al. (1990) suspected, a stimulation of stromal cells by inflammatory or (early) degenerative alterations, like Raila (2000) detected in ultrastructural investigations, leads to production of growth factors/mitogens which can influence epithelial proliferation. So in series, myofibroblastic differentiation of stromal cells could result in deviating functional stages of epithelial cells as also detectable in UGDareas of this study.

Although the results of the present study conclude that UGD is an early stage of endometrosis, further clinical and pathological follow-up studies are needed. They should verify if endometria with primarily only UGD develop endometrosis after a predefined period and could bring new knowledge about reversibility and actual/prospective fertility (Schoon and Schoon 2003, Häfner et al. 2001). As used by Walter et al. (2001), tropomyosin could confirm the presence of myofibroblasts and ultrastructural investigations could help to detect lesions resembling those, Ferreira-Dias et al. (1994) described in endometrosis.

A mare's endometrium needs to be differentiated in accordance with the ovarian stage of cycle to concept and carry her foal to term (Aupperle et al. 2000, Schoon et al. 1997). Endometria with UGD should not be able to fulfill this (Häfner et al. 2001), what can probably be explained by changes in uterine secretory protein pattern as Bader et al. (1997) described for endometritis and endometrosis (Häfner et al. 2001). Therefore, the prognostic significance of UGD must be considered as inappropriate in view of a successful pregnancy, because a progression to fibrotic nests is to be supposed with all consequences. 


\section{Acknowledgements}

The support of Mrs. Schleinitz and Mrs. Wipplinger in preparation and staining of the serial sections is thankfully acknowledged.

\section{References}

Aupperle H., Özgen S., Schoon H.-A., Schoon D., Hoppen H.-O., Sieme H., TannapfelA. (2000) Cyclical endometrial steroid hormone receptor expression and proliferation intensity in the mare. Equine Vet. J. 32, 228-232; DOI 10.2746/042516400776563554

Aupperle H., Schoon D., Schoon H.-A. (2004) Physiological and pathological expression of intermediate filaments in the equine endometrium. Res. Vet. Sci. 76, 249-255; DOI 10.1016/i. rvsc.2003.1 1.003

Aupperle H., Steiger K., Reischaver A., Schoon H.-A. (2003) Ultrastructural and immunohistochemical characterization of the physiological and pathological inactivity of the equine endometrium. Pferdeheilkunde 19, 629-632; DOI 10.21836/PEM20030611

Bader H., Kremer H., Vogt C., Schoon H.-A., Beier-Hellweg K. (1997) Investigation on the protein patterns of the equine uterine secretions as functional parameter of the endometrium. Pferdeheilkunde 13, 544; DOI 10.21836/PEM20030611

Brenner R. M., West N. B., McClellan M. C. (1990) Estrogen and progestin receptors in the reproductive tract of male and female primates. Biol. Reprod. 42, 11-19; DOI 10.1095/biolreprod42.1.11

Brunckhorst D., Schoon H.-A., Bader H., Sieme H. (1991) Morphologische, enzym-und immunhistologische Charakteristika des endometrialen Zyklus bei der Stute. Fertilität 7, 44-51

Doig P. A., McKnight J. D., Miller R. B. (1981) The Use of Endometrial Biopsy in the Infertile Mare. Can. Vet. J. 22, 72-76

Ellenberger C., Aupperle H., Bartmann C.-P., Hoppen H.-O., Schoon D., Schoon H.-A. (2002) Endometrial maldifferentiation caused by ovarian disorders in the mare - morphological and immunohistochemical results. Theriogenology 58, 499-502; DOI 10.1016/ S0093-691X(02)00817-8

Ferreira-Dias G., Nequin L. G., King S. S. (1994) Morphologic characteristics of equine endometrium classified as Kenney categories I, II, and III, using light and scanning electron microscopy. Am. J. Vet. Res. 55, 1060-1065; PMID 7978644

Häfner I. (1999) Differenzierungsstörungen im Endometrium der Stute. Lichtmikroskopische und immunhistologische Untersuchungen. Leipzig, Univ., Diss., 2000

Häfner I., Schoon H.-A., Schoon D., Aupperle H. (2001) Glanduläre Differenzierungsstörungen im Endometrium der Stute - Lichtmikroskopische und immunhistologische Untersuchungen. Pferdeheilkunde 17, 103-110; DOI 10.21836/PEM20010201

Hirschberger J. (1987) Development and characterization of monoclonal antibodies against chicken T-lymphocytes. Gießen, Justus-Liebig-Universität; Diss, 1987.
Hoffmann C. (2006) Morphologisch-funktionelle Untersuchungen zur Pathogenese der equinen Endometrose unter besonderer Berücksichtigung endometrialer Proteine und Kohlenhydrate. Leipzig, Univ., Diss., 2006

Kenney R. M. (1978) Cyclic and pathologic changes of the mare endometrium as detected by biopsy, with a note on early embryonic death. J. Am. Vet. Med. Assoc. 172, 241-262; PMID 621166

Kenney R. M. (1992) The aetiology, diagnosis and classification of the chronic degenerative endometritis. In Hughes J. P. (Ed.), International Workshop on Equine Endometritis, Newmarket, UK, 1992. Equine Vet. J. 25, 186

Kenney, R. M., Doig, P. A. (1986): Equine endometrial biopsy. In: Morrow D. A. (ed.): Current Therapy in Theriogenology 2. W. B. Saunders, Comp., Philadelphia, 723-729

Raila G. (2000) Zur Pathogenese der Endometrose der Stute. Morphologisch-funktionelle Untersuchungen. Leipzig, Univ., Diss., 2001

Mulisch M., Welsch U. in Romeis B. (2010) Romeis - Mikroskopische Technik, Springer, Heidelberg, 18. Aufl.

Sappino, A. P., Schürch W., Gabbiani G. (1990) Biology of disease: differentiation repertoire of fibroblastic cells - expression of cytoskeleton proteins as marker of phenotypic modulations. Lab. Invest. 63, 144-159; PMID 2116562

Schoon H. A., Schoon D., Klug E. (1992) Uterusbiopsien als Hilfsmittel für Diagnose und Prognose von Fertilitätsstörungen der Stute. Pferdeheilkunde 8, 355-362; DOI 10.21836/PEM19920603

Schoon H.-A., Schoon D., Ohnesorge B., Klug E. (1993): Zu Diagnose, Pathogenese und Bedeutung endometrialer Zysten bei der Stute. Pferdeheilkunde 9, 215-221; DOI 10.21836/PEM19930403

Schoon H.-A., Wiegandt I., Schoon D., Aupperle H., Bartmann C. P. (2000) Functional disturbances in the endometrium of barren mares: a histological and immunohistological study. J. Reprod. Fertil. Suppl. 56, 381-391; PMID 20681150

Schoon H.-A., Schoon D., Klug E. (1997) Die Endometriumbiopsie bei der Stute im klinisch-gynäkologischen Kontext. Pferdeheilkunde 13, 453-464; DOI 10.21836/PEM19970506

Schoon H.-A., Schoon D., Wiegandt I., Bartmann C.-P., Aupperle H. (1999) Endometrial maldifferentiation" - A clinically significant diagnosis in equine reproduction? Pferdeheilkunde 15, 555-559; DOI: 10.21836/PEM19990613

Schoon H.-A., Schoon D. (2003) The Category I mare (Kenney and Doig 1986): Expected foaling rate $80-90 \%$ - fact or fiction? Pferdeheilkunde 19, 698-701; DOI 10.21836/PEM20030626

Skalli O., Schürch W., Seemayer T., Lagace R., Montandon D., Pittet B., Gabbiani G. (1989) Myofibroblasts from diverse pathologic settings are heterogenous in their content of actin isoforms and intermediate filament proteins. Lab. Invest. 60, 275-285; PMID 2644484

Walter I., Handler J., Reifinger M., Aurich C. (2001) Association of endometrosis in horses with differentiation of periglandular myofibroblasts and changes of extracellular matrix proteins. J. Reproduct. Fert. 2001, 581-586; DOI 10.1530/rep.0.1210581 